\title{
Arresting Unemployment through Bee-Keeping: A Survey of Trainees from Leventis Agricultural Training School, Osun State, Nigeria
}

\author{
Anumudu Oluchi $\mathrm{O}^{1}$, Onugu, Charles $\mathbf{U}^{2}$, Obianefo Chukwujekwu $\mathrm{A}^{3}$, Enwelu, Innocent $\mathrm{A}^{4}$ \\ 1, 2, 3,4 Department of Agricultural Economics and Extension, Nnamdi Azikiwe University, Awka
}

\begin{abstract}
The study on arresting unemployment through bee-keeping; a survey of trainees from Leventis Foundation Agricultural Training School (LFATS), Osun State, Nigeria. Specifically looked into the socioeconomic characteristics of the trainees, estimation of the enterprise net returns and socioeconomic characteristics influence of LFATS on the net returns. A well-structured questionnaire was used to elicit information from randomly selected 148 bee- keeping trainees from Osun State based on the list made available by the LFATS management. The study used a combination of statistical tools such as descriptive statistics, budgetary model and ordinary least square (OLS) regression to achieve the study aim. Subsequently, the study revealed that the majority (79.5\%) of the trainees are male with mean age, experience and household size of 37 years, 8 years and 6 persons respectively. The net returns from bee-keeping enterprise were $\$ 230,002.54$ in the area with a return on investment of $\$ 2.64$ indicating that $\$ 1$ investment made in bee-keeping returns $\$ 2.64$ to the investor. Furthermore, the study revealed that sex ( $p>0.046)$, age ( $p>0.040)$ and level of education (p>0.035) were the socioeconomic variables that influence net returns from the bee-keeping enterprise. This therefore calls for the policymakers and management of Leventis Foundation Agricultural Training School (LFATS), Osun State, Nigeria to pay critical attention to the trainee's sex, age and level of education during the selection process for the training.
\end{abstract}

Keywords: bee-keeping, return on investment, net returns, trainees, enterprise, unemployment

\section{Introduction}

Unemployment is one of the major issues affecting Nigeria's economy and its society. The rate of unemployment has increased during the last few years due to the fallout from the economic challenges. Unemployment has become a major problem bedeviling the lives of Nigerian youths, causing increased militancy, violent crimes, kidnapping, restiveness, prostitution and socially delinquent behaviour (Ajufo, 2013). Nigeria as an agrarian country has over 196 million people in which $70 \%$ are engaged in agricultural production at subsistence level (World Bank Atlas, 2018) and provides sustenance for two-thirds of Nigerians who are low income earners (Usman, 2006; Ugwu and Kanu, 2012). Before the discovery of oil in the 60 (s), Nigeria earned about $60 \%$ of her gross domestic product (GDP) from agricultural sector sub-divided into crop production, livestock, fisheries, and forestry. Since the decline of agricultural contribution to the GDP, it only witnessed an all-time maximum of $29.15 \%$ in the fourth quarter of 2018 (Obianefo et al., 2019). Agriculture has contributed immensely to the African economy in various ways namely; in the provision of food for the increasing population, supply of adequate raw materials to a growing industrial sector, a major source of employment, generation of foreign exchange earnings, and provision of market for the products of the industrial sector among others (Nchuchuwe and Adejuwon, 2012). A lot of opportunities have been created in the agricultural sector in the form of agribusinesses which include crop production, animal production, poultry production, and agroforestry, bee-keeping among others.

Ajao and Oladimeji (2013) stated that Agriculture including bee-keeping offers unexploited succor capable of salvaging the people from abject hunger, unemployment and poverty. Creating renewed awareness and practice of bee-keeping in the rural setting would go a long way in eradicating global unemployment challenges. Ayansola (2012) quoted in Ajao and Oladimeji (2013) observed that bee-keeping can help to reduce the unemployment problem in Nigeria, especially in rural communities. In other words, bee-keeping which is an aspect of agriculture, scientifically called Apiculture is a self-reliance enterprise that can help reduce the hardship, unemployment and other social vices associated with poverty. Bee-keeping has become one of the major strategies of government in alleviating poverty, improving employment and improving the income of people (Augustina, 2017). It is an interesting agricultural enterprise that is not only beneficial through its products in terms of its medicinal value, nutritional value and anti-oxidant property, but also has minimal start-off capital, environmental friendliness and large markets for products. Akinmulewo (2016) asserted that the average honey output was $56.70 \mathrm{~kg}$ at the end of the circle with an estimated sales price of $\$ 700$ (\$1.93) per kilogram in Nigeria. According to a report put together by the officials of the Federal Ministry of Agriculture and Rural Development (FMARD), Nigerian Export Promotion Council (NEPC) and apiculture experts, Nigeria consumes about 400,000 tonnes of honey annually but produces less than 10 percent of its total consumption. Low yields from local farmers due to primitive methods of farming means that national bee production is less than national bee consumption, which by implication swells the national import bill by staggering figures to billions of dollars. (Retrieved from punchng.com, 28 November 2019).

The need to train bee-keeping entrepreneurs cannot be overemphasized as this will help to optimize their production capacity. Thus, Leventis Foundation Agricultural Training School (LFATS) is undertaking the responsibility of training entrepreneurs in agricultural skills which are targeted mainly to the women and youth. LFATS is a 


\section{International Journal of Science and Research (IJSR) \\ ISSN: 2319-7064}

ResearchGate Impact Factor (2018): 0.28 | SJIF (2018): 7.426

charitable company dedicated to the training of farmers in modern and sustainable agricultural practices and rational use of natural resources. The school is directed towards skill acquisition and capacity building in agriculture and agroallied businesses by adopting an integrated approach. The foundation has been running agricultural training for youths and farmers since 1987 and currently has six schools in the different agro-ecological zones in Nigeria. The schools are located in the Abuja, Osun, Kaduna, Kano, Ondo and Gombe states and are co-financed by Leventis foundation and the respective state governments. All the schools offer training to young people (male and female) desirous of making a good career in farming. The comprehensive training exposes the participants to several areas of agriculture and other businesses. The objective of the training, which is free for all, is to create generations of committed young practical farmers who will act as catalysts for agricultural revolution in their communities in Nigeria (Leventis Foundation Nigeria, 1999).

Considering the level of unemployment status (23.1\%) in Nigeria, the researchers are challenged on the need to explore LFATS training contribution to employment creation through bee-keeping. Specifically, the study tends to:

a) Describe the socioeconomic characteristics of the LFATS trained bee farmers,

b) Estimate the net returns from bee-keeping of the LFATS trained bee farmers, and

c) Ascertain the socio-economic characteristics of the LFATS trained bee farmers influence on their net return from bee-keeping in Osun state.

\section{Methodology}

A case study research design was adopted, therefore the researchers made use of a well-structured questionnaire in other to gather data used to address the research objectives. The study area is Osun State, Nigeria. The state is situated in the tropical rain forest zone. It covers an area of approximately $14,875 \mathrm{sq} \mathrm{km}$ and lies between latitude $7^{\circ} 30^{1}$ $0^{11} \mathrm{~N}$ and longitude $4^{\mathrm{o}} 30^{1} 0^{11} \mathrm{E}$. The people of the state are predominantly Yoruba. Their major occupation is farming. Being an agrarian state, agriculture is largely practiced both at commercial and subsistence scales and this attracts people from outside the state. The population of the study was made up of 236 bee-keeping farmers in Osun State trained by LFATS. Taro Yamene (1967) formula was used by the researcher to determine the sample size of the LFATS trained beekeeping farmers in Osun State which were randomly sampled. The study stratum is proportionately presented in Table 1 to explicitly show how the Local government areas were covered. Taro Yamene sample size determination in Otabor and Obahiagbon (2016) was further used to derive the sample size of the study. The formula is stated below as;

$$
\begin{aligned}
& n=\frac{N}{1+N(e)^{2}} \\
& n=\frac{236}{1+236(0.05)^{2}}=n=\frac{236}{1+0.59}
\end{aligned}
$$

Where:

$\mathrm{n}=$ sample size
$\mathrm{N}=$ population size

$\mathrm{e}=$ error margin

Therefore:

$\mathrm{N}=236$

$\mathrm{e}=0.05$

$\mathrm{n}=148$

Table 1: Population of LFATS trained bee-keeping farmers in Osun state

\begin{tabular}{|c|c|c|c|}
\hline Sn. & Local Government Areas & Population & Stratum \\
\hline 1 & Ilesa East & 56 & 35 \\
\hline 2 & Ife Central & 33 & 21 \\
\hline 3 & Osogbo & 42 & 26 \\
\hline 4 & Iwo & 24 & 15 \\
\hline 5 & Ede South & 23 & 14 \\
\hline 6 & Ife South & 22 & 14 \\
\hline 7 & Ifelodun & 36 & 23 \\
\hline Total & & 236 & 148 \\
\hline
\end{tabular}

Source: Field Survey Data, April 2019

\section{Data Analysis}

Statistical tools were employed to analyze the data that were collected in order to achieve the stated objectives of the study. The study, therefore, utilized a combination of analytical tools such as descriptive statistics, budgetary model and Ordinary Linear Square (OLS) regression. Objective 1 was achieved using descriptive statistics which includes frequency distribution, percentage and mean. Objective 2 was achieved using a budgetary model. Objective 3 was achieved using the Ordinary Linear Square (OLS) regression analysis.

A) The descriptive statistics for objective 1 is mathematically stated as;

$\bar{X}=\sum \frac{F X}{n}: 100$

Where:

$\bar{X}=$ mean

$\mathrm{X}=$ variable outcome

$\mathrm{n}=$ sample size

$\mathrm{F}=$ frequency

B). Budgetary model for objective 2 is stated thus;

$\mathrm{NR}=\mathrm{TR}-\mathrm{TC}(\mathrm{TFC}+\mathrm{TVC})$

Where:

$\mathrm{NR}=$ Net returns

$\mathrm{TR}=$ Total revenue

$\mathrm{TC}=$ Total cost

TFC $=$ Total fixed cost

$\mathrm{TVC}=$ Total variable cost

C). Ordinary Linear Square (OLS) regression for objective 3 is implicitly stated as;

$\mathrm{NR}=f\left(\mathrm{X}_{1}, \mathrm{X}_{2}, \mathrm{X}_{3}, \mathrm{X}_{4}, \mathrm{X}_{5}, \mathrm{X}_{6}, \mathrm{e}\right)$

Where:

$\mathrm{NR}=$ net return

$\mathrm{X} 1=$ Sex (dummy; $1=$ male, 2 = female)

$\mathrm{X} 2$ = Marital status (dummy; $1=$ single, $2=$ married, $3=$ widow/er, 4 = divorced/separated)

X3 = Age (years)

$\mathrm{X} 4=$ Level of Education (years)

$\mathrm{X} 5=$ Experience $($ years $)$

X6 = Household size (No) 


\section{International Journal of Science and Research (IJSR) \\ ISSN: 2319-7064}

ResearchGate Impact Factor (2018): 0.28 | SJIF (2018): 7.426

$\mathrm{F}=$ function

$\mathrm{e}=$ error term

\section{Results and Discussion}

Socioeconomic Characteristics of Trainees from Leventis Agricultural Training School, Osun State, Nigeria

The socioeconomic characteristics of the trainees are presented in Table 2. The Table shows that majority (79.5\%) of the trainees were male with mean age, farming experience and household size of 38 years, 8 years and 6 persons respectively. Thus, implying that the training is targeted at developing the entrepreneurial skills of the youths. The study equally affirmed that majority $(57.3 \%)$ of the trainees are married, this means that the training received will go a long way to improve the trainee's household livelihood status. Interestingly, the study equally showed that greater proportion $(41.8 \%)$ attended secondary school.

Table 2: Distribution of Bee Farmers according to their Socioeconomic Characteristics

\begin{tabular}{|c|c|c|c|c|}
\hline $\mathrm{Sn}$ & Variable & Frequency & $\begin{array}{c}\text { Percentage } \\
(\%)\end{array}$ & Mean \\
\hline \multirow[t]{3}{*}{1} & Sex & & & \\
\hline & Male & 175 & 79.5 & \\
\hline & Female & 45 & 20.5 & \\
\hline \multirow[t]{6}{*}{2} & Age (years) & & & \\
\hline & $\leq 20$ years & 27 & 12.4 & \\
\hline & 21years - 30years & 41 & 18.6 & 36.76 \\
\hline & 31years - 40years & 65 & 29.5 & \\
\hline & 41years - 50 years & 44 & 20.0 & \\
\hline & 51years and above & 43 & 19.5 & \\
\hline \multirow[t]{5}{*}{3} & Marital Status & & & \\
\hline & Single & 61 & 27.7 & \\
\hline & Married & 126 & 57.3 & \\
\hline & Divorced & 12 & 5.5 & \\
\hline & Widowed & 21 & 9.5 & \\
\hline \multirow[t]{5}{*}{4} & Level of Education & & & \\
\hline & Primary & 39 & 17.7 & \\
\hline & Secondary & 92 & 41.8 & \\
\hline & Tertiary & 70 & 31.8 & \\
\hline & No formal education & 19 & 8.6 & \\
\hline \multirow[t]{6}{*}{5} & Bee Keeping Experience (years) & & & \\
\hline & $\leq 2$ & 12 & 5.5 & \\
\hline & $3-5$ & 22 & 10.0 & 8.40 \\
\hline & $6-8$ & 77 & 35.0 & \\
\hline & $9-11$ & 50 & 22.7 & \\
\hline & $12-$ above & 59 & 26.8 & \\
\hline \multirow[t]{6}{*}{6} & Household size (person) & & & \\
\hline & $\leq 2$ & 43 & 19.5 & \\
\hline & $3-5$ & 64 & 29.1 & \\
\hline & $6-8$ & 80 & 36.4 & 5.50 \\
\hline & $9-11$ & 22 & 10.0 & \\
\hline & 12 and above & 11 & 5.0 & \\
\hline
\end{tabular}

Source: Field Survey Data, April 2019

\section{Trainees Net Returns}

The estimated net returns of trainees from bee keeping enterprise are presented in Table 3. The Table shows that the total operational expenses (Total Variable cost) incurred in bee keeping enterprise was $\$ 75357.38$, while the Total Fixed Cost was $\$ 11735.53$. Thus, the total cost (TC) expended in the bee keeping enterprise by the trainees from Leventis Agricultural Training School, Osun State, Nigeria was 87092.91. It is equally worthy to note that the mean revenue generated from the sales of the honey by the trainees was $\$ 317,095.45$. At the end of the estimation, the researcher found that the net returns from the enterprise were $\$ 230,002.54$, while the return on investment (ROI) was 2.64. This implies that for every $\$ 1$ investment made in bee keeping in the study area by the trainees will generate a profit of 2.64 . Thus, one can infer that bee keeping is a profitable venture.

Table 3: Trainees Net Returns

\begin{tabular}{|c|c|c|c|c|}
\hline Sn. & Item & Quantity & Unit price (\#) & Value (\#) \\
\hline 1 & Revenue & & & \\
\hline & Honey & 141.46 & 2241.59 & $\mathbf{3 1 7 , 0 9 5 . 4 5}$ \\
\hline 2 & Variable cost & & & \\
\hline & Labour & - & - & $22,121.95$ \\
\hline & Logistics & - & - & $53,235.43$ \\
\hline & Total variable cost & & & $\mathbf{7 5 3 5 7 . 3 8}$ \\
\hline 3 & Fixed cost & & & \\
\hline & $10 \%$ Dep. On Beehive & 7.07 & 1211.37 & 8564.39 \\
\hline & $10 \%$ Dep. on Equipment & - & - & 3171.14 \\
\hline & Total fixed cost & & & $\mathbf{1 1 7 3 5 . 5 3}$ \\
\hline 4 & Total cost & & & $\mathbf{8 7 0 9 2 . 9 1}$ \\
\hline 6 & Net return & & & $\mathbf{2 3 0 , 0 0 2 . 5 4}$ \\
\hline 7 & Return on Investment & & & $\mathbf{2 . 6 4}$ \\
\hline
\end{tabular}

Source: Field Survey Data, April 2019

\section{Socioeconomic characteristics influence on Net returns}

The socioeconomic characteristics influence on trainee's net return is presented in Table 4. The ordinary least square regression model was used to ascertain the trainee's socioeconomic characteristics influence on their net returns from bee farming enterprise. The coefficient of multiple determinants $\left(\mathrm{R}^{2}\right)$ was 0.5853 signifying that $58.53 \%$ of the dependent variable (net return) was explained by the joint action of the independent variables (trainees socioeconomic characteristics), while the remaining $41.47 \%$ was as a result of the error beyond the control of the trainees. The intercept was significant at $1 \%$ level of probability, also, when all the socioeconomic variables are held constant, the net return of the trainees is expected to increase by $\$ 617777.9$. Thus, the model was estimated as follows;

$\mathrm{NR}=617777.9-326036 \mathrm{X}_{1}+116485.5 \mathrm{X}_{2}+14277.15 \mathrm{X}_{3}-$ $40633.78 \mathrm{X}_{4}+18341.83 \mathrm{X}_{5}-16343.55 \mathrm{X}_{6}$

Furthermore, the coefficient of marital status, experience and household size were not significant at either $5 \%$ or $1 \%$ level of probability.

The coefficient of sex (326036) was negative and significant at $5 \%$ level of probability. This implies that a 5\% increase in the number of female trainees will reduce the net returns bee farming by $\$ 326036$. This could be associated with the physicality of agricultural enterprise.

The coefficient of age (14277.15) was positive and significant at $5 \%$ level of probability. This implies that a unit increase in the age of the targeted trainees will increase their net returns from bee farming by 5\% (\$14277.15). In agriculture, age is associated with the experience, therefore, the older the farmers, the more experience and patient they will be to bring about the needed profit.

The coefficient of the trainee's level of education was negative and significant at 5\% level of probability. This

\section{Volume 9 Issue 1, January 2020}




\section{International Journal of Science and Research (IJSR) \\ ISSN: 2319-7064}

ResearchGate Impact Factor (2018): 0.28 | SJIF (2018): 7.426

implies that a $5 \%$ increase in the number of less educated trainees will reduce the net returns from bee farming by \$40633.78. The more educated the trainees are, the more chances they will adopt modern methods of bee keeping. This result was expected as many rural agricultural and entrepreneurial skills are usually targeted at less educated who are more less considered vulnerable individuals.

Thus, the variables that influence the net returns of trainees were sex, age and level of education.

Table 4: Socioeconomic characteristics influence on Net returns

\begin{tabular}{|c|c|c|c|c|}
\hline Variable & Coefficient & Standard error & $\mathrm{t}$-ratio & $\mathrm{p}>|\mathrm{t}|$ \\
\hline Sex & -326036 & 162308.1 & $-2.01^{*}$ & 0.046 \\
\hline Marital status & 116485.5 & 116943.1 & 1.00 & 0.320 \\
\hline Age & 14277.15 & 6912.379 & $2.07^{*}$ & 0.040 \\
\hline level of Education & -40633.78 & 19196.77 & $-2.12^{*}$ & 0.035 \\
\hline Experience & 18341.83 & 13835.92 & 1.33 & 0.186 \\
\hline Household size & -16343.55 & 19619.67 & -0.83 & 0.406 \\
\hline cons & 617777.9 & 149259.1 & $4.14^{* *}$ & 0.000 \\
\hline $\mathrm{R}^{2}$ & 0.5853 & & & \\
\hline F-stat & $4.42^{* *}$ & & & \\
\hline $\mathrm{n}$ & 148 & & & \\
\hline
\end{tabular}

Source: Field Survey Data, April 2019. (*) Significant at 5\% and (**) Significant at $1 \%$

\section{Conclusion and Recommendations}

The need to arrest unemployment through the various agricultural programme cannot be overemphasized. Thus, Leventis Foundation Agricultural Training School, Osun State, Nigeria is playing a critical role in bringing about economic stability in the country through entrepreneurial empowerment. The center is involved in upgrading the economic performance in the agricultural sector. Arresting unemployment through training in bee keeping is an important area to look into as capital investment in the sector is minimal while returns is good and could be highly sustainable. Indeed, the need to reduce the consumption of industrial sugar has increased the demand for bee-products as well as its anti-oxidant benefit. As evidenced, the center concentrated most of its training to the youths who are more hit by the incidence of unemployment. With the findings indicating the viability of the enterprise as 1 investment made gave rise to 2.64 , Non-governmental Organizations such as Leventis Foundation Agricultural Training School (LFATS), and others should be encouraged and supported to spread this very productive corporate responsibility initiative in reducing youth unemployment situation in Nigeria. Therefore, based on this study and the need to strengthen the noble work of LFATS, the following recommendations are made:

1) The government and non-governmental organizations should organize more bee-keeping and processing trainings at a larger scale so as to accommodate more people especially females.

2) Establishment of bee farmer's cooperative association for easily accessing financial aids, marketing information and inputs from government and non-governmental organizations through poverty alleviation agencies.

\section{References}

[1] Ajao, A.M. and Y.U. Oladimeji (2013). Assessment of Contribution of Apicultural Practices to Household Income and Poverty Alleviation in Kwara State, Nigeria. International Journal of Science and Nature, vol.4 (4): 687-698.

[2] Ajufo, B.I. (2013). Challenges of Youth Unemployment in Nigeria: Effective Career Guidance as a Panacea. An International Multidisciplinary Journal, Ethiopia. Vol. 7 (1), Serial No. 28, January 2013: 307-321. ISSN 1994-9057 (Print). ISSN 2070-0083 (Online).

[3] Akinmulewo, B.O. (2016). Assessment of the Profitability of Improved Agriculture and its relationship to poverty status in Abuja, Nigeria. An unpublished Msc thesis in Agricultural Economics and Rural Sociology, Ahmadu Bello University, Zaria, Kaduna state.

[4] Augustina, U.N. (2017). Adoption of modern honey bee production and processing practices among farmers in Kano state, Nigeria. An unpublished Msc. thesis from the Department of Vocational and Technical Education, Ahmadu Bello University, Zaria.

[5] Ayansola, A.A. (2012). An Appraisal of Apicultural Practices in Southwestern Nigeria. Journal of Agricultural Science. 3(2): 79-84.

[6] Nchuchuwe, F.F. and K.D. Adejuwon (2012). The challenges of Agriculture and Rural Development in Africa: The case of Nigeria. International Journal of Academic Research in Progressive Education and Development. July 2012, vol. 1, No. 3. ISSN: 22266348.

[7] Obianefo, C.A., I.P. Okafor, I. Bola-Audu and E.E. Umebali (2019).Assessment of the Education Background on Perception of Single Digit Interest Rate among Members of Farmers' Cooperative in Anambra State. International Journal of Trend in Scientific Research and Development. Vol. 3(5), pp. 113-117.

[8] Otabor, J.O. and K. Obahiagbon (2016). Statistical Approach to the link between Internal Service Quality and Employee Job Satisfaction: A case study. American Journal of Applied Mathematics and Statistics. 4(6), pp. 178-184. DOI: 10.12691/ajams-4-6-3.

[9] The Leventis Foundation Nigeria. (1999) - Second Edition Revised. Pp. 5-23.

[10] Ugwu, D.S. and I.O. Kanu (2012). Effects of Agricultural reforms on the Agricultural sector in Nigeria. Journal of African studies and Development. Vol. 4(2), pp. 51-59, March 2012. ISSN 2141 - 2189.

[11] Usman, N.E. (2006). Agriculture: vital to Nigerian Economic Development. Paper presented at the forum of Economic stakeholders on growing the Nigerian Economy 2006. ThisDay Newspaper, July 25, 2006.

[12] World Bank Atlas (2018). Nigeria total population. 